Check for updates

Cite this: RSC Adv., 2017, 7, 37065

Received 20th May 2017

Accepted 5th July 2017

DOI: $10.1039 / \mathrm{c} 7 \mathrm{ra05690g}$

rsc.li/rsc-advances

\section{Fate and transformation of nanoparticles (NPs) in municipal wastewater treatment systems and effects of NPs on the biological treatment of wastewater: a review}

\begin{abstract}
Shutao Wang, (D) *a Zhisheng Liu, ${ }^{\mathrm{b}}$ Weiqing Wang ${ }^{\mathrm{a}}$ and Hong You ${ }^{\mathrm{ac}}$
Many types of nanoparticles (NPs) have been reported to be toxic to organisms. Wastewater treatment plants are among the important pathways for the migration and transformation of NPs in the environment. Based on a summary of the toxicity of NPs to microorganisms, this review discusses the advances in the fate and transformation of NPs in wastewater treatment plants (WWTPs) and the impacts of NPs on the biological treatment of wastewater. These NPs primarily include Ag NPs, Cu NPs, CuO NPs, $\mathrm{ZnO} N P s, \mathrm{TiO}_{2} \mathrm{NPs}, \mathrm{Al}_{2} \mathrm{O}_{3} \mathrm{NPs}, \mathrm{SiO}_{2} \mathrm{NPs}$, carbon nanotubes (CNTs) and magnetic NPs. This review observes that the different properties of these NPs result in significant differences in the fate, transformation, antimicrobial activities and effects on biological wastewater treatment. Although many studies have been undertaken in this field, more studies are needed to address the adverse effects of NPs on organic and nutrient removal, as well as their toxic mechanisms.
\end{abstract}

${ }^{a}$ State Key Laboratory of Urban Water Resource and Environment, Harbin Institute of Technology, 73, Huanghe Rd., Nangang Dist., Harbin 150090, China. E-mail: wshutao@hit.edu.cn; 734067974@qq.com; youhong@hit.edu.cn

${ }^{b}$ Changchun Institute of Urban Planning \& Design, 8888, Ziyoudalu, Changchun 130033, China.E-mail: chinalzs@163.com

'2, Wenhuaxi Rd.,, Huancui Dist., Weihai 264209, China

\section{Introduction}

Nanomaterials and nanotechnology have affected human life in many ways. Many types of nanoparticles (NPs), such as carbon nanotubes (CNTs), zinc oxide (ZnO NPs), titanium dioxide $\left(\mathrm{TiO}_{2}\right.$ $\mathrm{NPs})$, manganese oxide $\left(\mathrm{MnO}_{2} \mathrm{NPs}\right)$, copper oxide (CuO NPs) and copper (Cu NPs), and silver (Ag NPs), have been widely used in such applications as medicines, pesticides, alternative energy, catalysts, and consumer products. ${ }^{1}$ For example, ${ }^{2} \mathrm{Ag}$

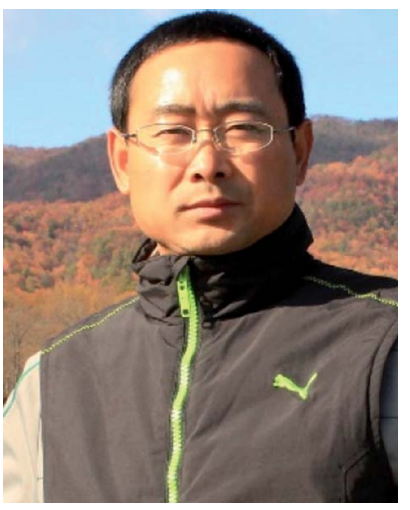

Dr WANG Shutao received his M. and Ph.D. degrees in Environmental Science and Municipal Engineering, respectively, from Harbin Institute of Technology (HIT), China. He has been an assistant prof. of School of Municipal and Environmental Engineering of HIT, since 2008. His research interests focus on environmental toxicity, including the environmental behavior of toxic substances and nanoparticles (NPS) and biological toxicity of typical pollutants in the environment. His interests also concentrate on advanced treatment of refractory wastewater by advanced oxidations. He has more than forty publications so far, including papers and books.

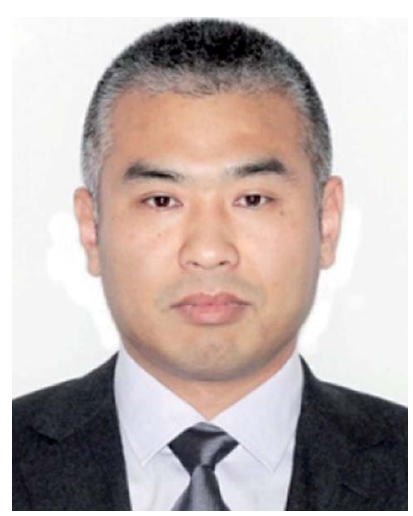

Dr LIU Zhisheng received his $M$. and Ph.D. degrees in Municipal Engineering from Harbin Institute of Technology (HIT), China. He has been the vice dean since 2008. His research interests focus on ecological toxicity of pollutants in the environment and the pollution control of rivers. He also works on ecological planning of city. 
NPs have been used as an antibacterial agent due to their antiseptic properties in children's toys, clothing and washing machines. $\mathrm{Cu}$ NPs have been applied in bioactive coatings, air and liquid filtration, skin care products, wood preservatives, textiles, and coatings on integrated circuits. During the production and applications of nanomaterials, a portion of them will likely enter the environment. Owing to their large surface area and small size ( 1 to $100 \mathrm{~nm}$ ), nanoparticles (NPs) possess special physical and chemical properties. The ecotoxicological evaluation of NPs is an equally important problem. ${ }^{3}$ In recent years, a number of ecotoxicological studies have been carried out on NPs in aquatic organisms, such as bacteria, cells, algae, and zooplankton. ${ }^{4-7}$

It is known that wastewater treatment plants (WWTPs) are one of the most important pathways for NPs to enter the environment. ${ }^{8,9}$ Activated sludge in WWTPs, a suspended microbial aggregate playing a primary role in pollutants removal, contains many types of microorganisms and their extracellular products. Because NPs have been shown to be toxic, their impacts on the functional microorganisms of activated sludge are worth studying. Numerous published studies have investigated this subject.

The present review begins with a summary of the toxicity of various NPs to microorganisms. We summarize and review the fate and transformation of NPs in wastewater treatment systems, as well as the effects of NPs on the performance of biological nitrogen removal, phosphorus removal and microbial communities for the degradation of organic pollutants. We also advance our own views on the aspects that are incomplete and warrant further research.

\section{Effects of NPs to microorganisms}

The increasing use of metal and metal oxide nanomaterials leads to the discharge of nanomaterials into the environment. Many researchers have evaluated these materials' toxicity to microorganisms. ${ }^{10}$ The inhibitory effect of Ag NPs and Au NPs on microorganisms in a modern WWTP was reported using realistic activated sludge. ${ }^{11}$ This research indicated that $100 \mathrm{mg}$ $\mathrm{L}^{-1} \mathrm{Ag}$ NPs is intermediately toxic to ordinary heterotrophic organisms (OHO) (by 33\% of inhibition), while Au NPs show no or very low toxicity to $\mathrm{OHO}$, ammonia oxidizing bacteria (AOB), and anaerobic biomass at the concentration of $90 \mathrm{mg} \mathrm{L}^{-1}$. At low concentrations $\left(<5 \mathrm{mg} \mathrm{L}^{-1}\right)$, Ag NPs do not affect anaerobic degradation, resulting in functional redundancy built within the microbial community. ${ }^{12}$ In addition, the toxicity of Ag NPs to different microorganisms greatly differs, being the lowest $\left(0.1 \mathrm{mg} \mathrm{L}^{-1}\right)$ for crustaceans and algae, and the highest $(26 \mathrm{mg}$ $\mathrm{L}^{-1}$ ) for mammalian cells. ${ }^{13}$ The toxicity of $\mathrm{Ag}$ NPs is also affected by coexisting substances, e.g., sulphide. The presence of sulphide reduces the toxicity of Ag NPs to C. riparius, because sulphide can decrease the release of $\mathrm{Ag}^{+}$from $\mathrm{Ag}$ NPs. ${ }^{\mathbf{1 4}}$

ZnO NPs toxicity is related to the species of bacteria. $10 \mathrm{mg}$ $\mathrm{L}^{-1} \mathrm{ZnO}$ NPs can cause significant growth inhibition (up to $90 \%$ ) in Bacillus subtilis but only cause $22 \%$ of the growth inhibition in Escherichia coli (E. coli). ${ }^{15}$ Moreover, ZnO NPs can induce the production of oxidative stress, causing cell membrane damage and cytoplasmic leakage owing to lipid peroxidation (LPO) at concentrations higher than $1.3 \times 10^{-3} \mathrm{M}$ (105 $\mathrm{mg} \mathrm{L}^{-1}$ ) in a liquid culture medium. ${ }^{16}$ In addition, ZnO NPs can also cause microbial biomass reduction, bacterial community shift and diversity decline in bacterial communities at $60 \mathrm{mg} \mathrm{L}^{-1}$ in activated sludge in an SBR. ${ }^{17}$

$\mathrm{TiO}_{2}$ NPs have been detected in wastewater and sewage sludge. Even though the predicted concentration of $\mathrm{TiO}_{2} \mathrm{NPs}$ is at the $\mu \mathrm{g} \mathrm{L}^{-1}$ level $^{18}$ in the aquatic environment, their release into the environment increases because of their increasing production and application. Most results indicate that $\mathrm{TiO}_{2} \mathrm{NPS}$ do not have a strong toxicity to microorganisms, even at the concentration of $500 \mathrm{mg} \mathrm{L}{ }^{-1}$ in short-term treatments. ${ }^{19} \mathrm{TiO}_{2}$ NPs also do not show significant toxicity ${ }^{20-22}$ at concentrations of $<50 \mathrm{mg} \mathrm{L}^{-1}$ in long-term treatments.

The toxicity of CuO NPs to some bacteria has been reported in recent years. CuO NPs $\left(2.5 \mathrm{mg} \mathrm{L}^{-1}\right)$ can decrease the total nitrogen (TN) removal rate by $22.4 \%$, but the removal can be recovered under certain conditions. ${ }^{23} \mathrm{CuO}$ NPs exhibit high toxicity to Escherichia coli at the concentration of $10 \mathrm{mg} \mathrm{L}^{-1}$, but fulvic acid (FA) can reduce the toxicity significantly. ${ }^{24}$ Additionally, the exposure to $50 \mathrm{mg} \mathrm{\textrm {L } ^ { - 1 }} \mathrm{CuO}$ NPs results in a significant inhibition to the respiration activity of the bacteria of biofilms. ${ }^{23}$

Only a limited number of reports are found examining the toxicity of $\mathrm{Al}_{2} \mathrm{O}_{3}$ NPs to certain organisms. Specifically, $20 \mathrm{mg}$ $\mathrm{L}^{-1} \mathrm{Al}_{2} \mathrm{O}_{3}$ NPs can induce a mortality rate of $57 \%$ in Bacillus subtilis, $36 \%$ in E. coli, and $70 \%$ in Pseudomonas fluorescens using $1 \mathrm{~g} \mathrm{~L}^{-1} \mathrm{NaCl}$ as the experimental medium, ${ }^{25}$ while in a nutrient enriched test medium, $\mathrm{Al}_{2} \mathrm{O}_{3}$ NPs can create an antimicrobial property towards Escherichia coli and exhibit a nominal growth inhibitory effect only at very high concentrations $\left(>1 \mathrm{~g} \mathrm{~L}^{-1}\right) .{ }^{26}$ For a dominant bacteria, Bacillus licheniformis, isolated from freshwater (lake water), exposure to $1 \mathrm{mg}$ $\mathrm{L}^{-1} \mathrm{Al}_{2} \mathrm{O}_{3} \mathrm{NPs}$ for $2 \mathrm{~h}$ can cause a decrease in cell viability by $17 \% .{ }^{27} \mathrm{Al}_{2} \mathrm{O}_{3}$ NPs present mild-level toxic effects on the growth of bacteria only at very high concentrations, which results from surface charge interactions between the bacteria and $\mathrm{Al}_{2} \mathrm{O}_{3}$ NPs. The ROS scavenging properties of $\mathrm{Al}_{2} \mathrm{O}_{3}$ NPs prevent cell wall disruption and drastic antimicrobial action. In addition, $\mathrm{Al}_{2} \mathrm{O}_{3}$ NPs can significantly inhibit Escherichia coli growth and prevent the adsorption of $\mathrm{Al}_{2} \mathrm{O}_{3}$ NPs onto the cell surface. ${ }^{28}$ The intracellular $\mathrm{Al}_{2} \mathrm{O}_{3}$ NPs can interact with cellular biomolecules and cause adverse effects, eventually triggering cell death.

$\mathrm{SiO}_{2}$ nanomaterials are widely used in domestic products and the potential toxicity to model organisms has been reported in zebrafish embryos, lung epithelial cells and other cell lines. ${ }^{29,30}$ Some studies have explored the potential toxicity of $\mathrm{SiO}_{2} \mathrm{NPs}$ to bacteria. One study reports that $\mathrm{SiO}_{2}$ NPs can kill $40 \%$ of Bacillus subtilis, $58 \%$ of Escherichia coli, and $70 \%$ of Pseudomonas fluorescens in experimental culture mediums when the exposure concentration reaches $20 \mathrm{mg} \mathrm{L}{ }^{-1} \cdot{ }^{25}$ At the concentrations of 0.05 to $1.0 \mathrm{~g} \mathrm{~L}^{-1}, \mathrm{SiO}_{2} \mathrm{NPs}$ have different effects on the antiradical activity of the culture medium (CM) of Bacillus subtilis IMV B-7023, and low doses of $\mathrm{SiO}_{2}$ NPs can stimulate the reducing power of the $\mathrm{CM}$ of bacteria and strongly inhibit it in consequence. ${ }^{31}$ By comparison, $\mathrm{SiO}_{2}$ NPs have less 
power than Ag NPs against the oral pathogenic species Streptococcus mutans. ${ }^{32}$

Similar to magnetic nanoparticles (MNPs), nano zero-valent iron (nZVI) and magnetite $\left(\mathrm{Fe}_{3} \mathrm{O}_{4}\right)$ are widely used in water treatment. These applications make MNPs likely to enter the environment, and then get into WWTPs. ${ }^{33}$ nZVI can penetrate cellular membranes and get into living cells,$^{34}$ which results in the accumulation of NPs in living organisms. Two other toxicological studies ${ }^{35,36}$ showed that nZVI can rapidly inactivate Escherichia coli, Pseudomonas fluorescens and Bacillus subtilis var. niger, but Aspergillus versicolor is not affected by them. Some microorganisms can be positively affected by nZVI. For example, methanogens are significantly stimulated by nZVI, and methane production is increased while dechlorinating organisms are inhibited. ${ }^{37}$

There are two types of carbon nanotubes (CNTs), namely, multi-walled carbon nanotubes (MWCNTs) and single-walled carbon nanotubes (SWCNTs). The microbial toxicity of CNTs has been demonstrated under different conditions. The toxicity of CNTs to microorganisms is believed to be related to physical properties (length and diameter), concentration, and types of functionalization. ${ }^{38-41}$ It was reported that Staphylococcus warneri and Staphylococcus aureus are not able to grow over MWCNTs films. ${ }^{42}$ Both SWCNTs and MWCNTs at concentrations of $5 \mathrm{mg} \mathrm{L}{ }^{-1}$ are demonstrated to have antimicrobial activity towards Escherichia coli. ${ }^{43}$ Long SWCNTs $(5-30 \mu \mathrm{m})$ can cause significantly greater reductions in the viability of entrapped cells of Escherichia coli than short SWCNTs at concentrations of 5-200 mg L ${ }^{-1}{ }^{44}$ When a phenol wastewater treatment system is exposed to SWCNTs $\left(2.5 \mathrm{~g} \mathrm{~L}^{-1}\right)$ over an extended period, the structure, richness and diversity of microbial communities are shifted. ${ }^{45}$ The effect of MWCNTs on upflow anaerobic sludge blanket (UASB) microflora shows that the reduction in a colony-forming unit (CFU) reaches $29 \%$ and $58 \%$ at MWCNTs concentrations of 1 and $100 \mathrm{mg} \mathrm{L}^{-1}$, respectively. ${ }^{46}$

In summary, most of the NPs mentioned above are toxic to microorganisms at certain concentrations, which makes it necessary to identify the possible adverse effects of them on the microbial activities of activated sludge in wastewater treatment plants.

\section{Fate and transformation of NPs during the biological treatment of municipal wastewater}

NPs released from different nanomaterials are finding their way to wastewater treatment tanks and end up in wastewater sludge. ${ }^{47-49}$ It is essential to investigate the fate and transformation of NPs to evaluate the potential environmental impacts on wastewater treatment systems. Many research findings indicate that for the removal of NPs, such as Ag NPs, $\mathrm{Cu}$ NPs, ZnO NPs, $\mathrm{TiO}_{2}$ NPs, $\mathrm{CuO}$ NPs and $\mathrm{CeO}_{2} \mathrm{NPs}$, from wastewater, multiple mechanisms are involved, including the physical entrapment of NPs into the floc, active cellular uptake, and binding to extracellular polymers substances (EPS) or bacteria surfaces. ${ }^{50,51}$ Regardless of the mechanisms of removal, most NPs can be removed from suspension with the primary and/or secondary solids that are settled, wasted, and dewatered to form biosolids. Namely, only a very small fraction of NPs are discharged with the treated effluent. ${ }^{52}$ For example, it is estimated that only $6 \%$ of $\mathrm{CeO}_{2} \mathrm{NPs}$ are transmitted through a WWTP, ${ }^{53}$ and $95 \%$ of $\mathrm{Cu}$ NPs are removed from wastewater. ${ }^{54}$ The predominant mechanisms of copper removal appear to be aggregation and settling ( $\mathrm{Cu}$ NPs), rather than biosorption. In addition, ZnO NPs are also efficiently removed from wastewater, with an insignificant portion being released into the environment through the treated effluent. ${ }^{55} \mathrm{~A}$ large percentage of $\mathrm{ZnO}$ NPs settle out into the sludge. Under wastewater conditions, most NPs aggregate and are attached to the biomass.

Silver can bind strongly to sulphur (both organic and inorganic) in WWTPs, and most Ag NPs are concentrated and then removed ${ }^{56}$ Additionally, most of the Ag NPs in both effluent and sludge are present in the form of $\mathrm{Ag}_{2} \mathrm{~S}^{.77}$ The almost complete removal of citrate-coated Ag NPs is achieved from a simulated sequencing batch reactor (SBR)..$^{58} \mathrm{Ag}$ NPs are efficiently transported into sewer systems without substantial losses to the sewer biofilm. ${ }^{59}$ Therefore, Ag NPs can be efficiently removed from wastewater treatment systems.

Raw sewage titanium concentrations range from 181 to 1233 $\mu \mathrm{g} \mathrm{L}^{-1}$ in 10 representative WWTPs in the United States. The WWTPs can remove more than $96 \%$ of the influent $\mathrm{TiO}_{2} \mathrm{NPs}$, and the effluent titanium concentrations are less than $25 \mu \mathrm{g} \mathrm{L}$ in all WWTPs. ${ }^{60}$

In many cases, $>90 \%$ of NPs from sewage appear to be removed, but poor removal efficiencies of $\mathrm{SiO}_{2}$ NPs have been reported. For example, the flocculation and sedimentation processes used in primary wastewater treatment are shown to be ineffective in removing $56 \mathrm{~nm} \mathrm{SiO}{ }_{2} \mathrm{NPs}$ at $2470 \mathrm{mg} \mathrm{L}^{-1}$ due to their stability and slow settling rate. ${ }^{61}$ In another study, ${ }^{62} 96 \%$ of $\mathrm{SiO}_{2} \mathrm{NPs}$ was effectively removed from the wastewater during the first $6 \mathrm{~d}$, while the concentration of $\mathrm{SiO}_{2} \mathrm{NPs}$ in the effluent gradually increased afterwards, and the NPs discharge was as high as $65 \%$ of the input after $30 \mathrm{~d}$ of $\mathrm{SiO}_{2} \mathrm{NPs}_{\text {dosing. The poor }}$ removal of the $\mathrm{SiO}_{2}$ NPs is related to the high colloidal stability of the $\mathrm{SiO}_{2}$ NPs in the wastewater and their limited propensity to biosorption.

There are many environmental factors affecting the migration and transformation of NPs. Dissolution, aggregation and agglomeration are the main factors affecting the state of metal NPs in suspensions. ${ }^{63}$ Additionally, the salinity also affects the activated sludge and its microorganisms. ${ }^{64}$ These processes will consequently impact the bioavailability, uptake, and toxicity of NPs. ${ }^{65,66}$ Various properties of the exposure media can influence the dissolution and aggregation of metal NPs, e.g. ionic strength, $\mathrm{pH}$ and the presence of natural organic matters (NOM) ${ }^{67}$

The release of $\mathrm{Zn}^{2+}$ from $\mathrm{ZnO}$ NPs in wastewater is more significant under acidic conditions and low ionic strength, but under alkaline conditions, most of the ZnO NPs show a strong affinity for the sewage sludge rather than dissolved or dispersed in the filtrate. ${ }^{68,69}$ It was found that the dissolution or ion release of Cu NPs occurs in wastewater treatment systems. ${ }^{70} \mathrm{Ag}$ NPs can 
Table 1 Summary of fate and transformation of some NPs during the biological treatment of municipal wastewater

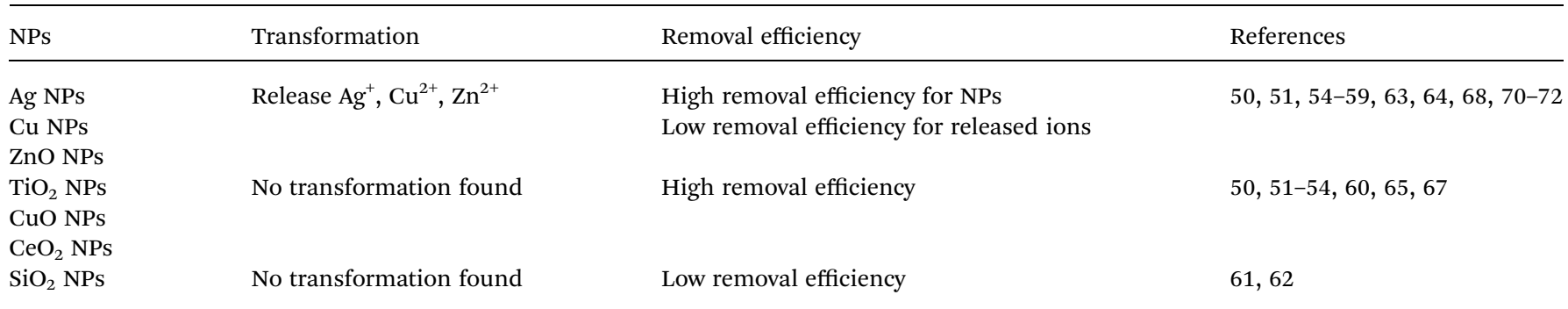

be transformed into $\mathrm{Ag}^{+}$under certain conditions, which were found to be more toxic than Ag NPs to the microbial communities in activated sludge and the nitrification process. However, DOM can significantly stabilize Ag NPs. ${ }^{71}$ Sulphidation can lead to Ag NPs and ZnO NPs aggregation. ${ }^{72} \mathrm{ZnO}$ NPs are slightly soluble and can dissolve to form $\mathrm{Zn}^{2+}$ under aqueous conditions. This finding suggests that the released $\mathrm{Zn}^{2+}$ is responsible for the toxicity of ZnO NPs to Mycobacterium smegmatis ${ }^{73}$ and Pseudokirchneriella subcapitata. ${ }^{74}$ However, Shewanella oneidensis MR-1 and Escherichia coli are insensitive to the released $\mathrm{Zn}^{2+}$ even though the concentrations of ZnO NPs are higher than $40 \mathrm{mg} \mathrm{L}^{-1} \cdot{ }^{73}$

Overall, the data collected indicate that biological WWTPs operated using activated sludge can effectively remove most types of NPs from wastewaters. Such NPs as Ag NPs, ZnO NPs, and $\mathrm{TiO}_{2}$ NPs can be efficiently removed through their interaction with biomass. Ag NPs, Cu NPs and ZnO NPs would be partially transformed into $\mathrm{Ag}^{+}, \mathrm{Cu}^{2+}$ and $\mathrm{Zn}^{2+}$, respectively, under certain conditions. The presence of both EPS and ionic compounds can effectively enhance the NPs removal. The instability of the NPs resulting from the ionic strength in sewage and the entrapment of NPs by EPS play important roles in NPs removal by activated sludge. Table 1 is a summary of the fate and transformation of NPs during the biological treatment of municipal wastewater.

\section{Effects of NPs on performances of biological treatment of municipal wastewater}

\subsection{Effects of NPs on nitrification and denitrification}

Many studies have been conducted on the effects of Ag NPs on functional microorganisms and microbial communities in biological wastewater treatment processes. For example, among nitrogen-cycling bacteria, the nitrifier Nitrosomonas europaea is more sensitive to Ag NPs when the concentration is higher than $1.44 \mathrm{mg} \mathrm{L}^{-1}$ compared to the denitrifier Pseudomonas stutzeri and the nitrogen fixer Azotobacter vinelandii. ${ }^{75} \mathrm{Ag}$ NPs at concentrations $>2 \mathrm{mg} \mathrm{L}^{-1}$ can induce damage of the cell wall and membrane of Nitrosomonas europaea, and disorganize the nucleoids. ${ }^{76}$ In addition, Ag NPs can inhibit important protein functions, including biosynthesis, energy production, gene expression and nitrification in the test media at $5 \mathrm{mg} \mathrm{L}^{-1} \cdot{ }^{.7}$ García et al. ${ }^{11}$ reported the inhibitory effects of Ag NPs on the activity of microbial communities in activated sludge systems through respiration tests and biogas-production analysis. Ag NPs at the concentration of $0.1 \mathrm{mg} \mathrm{mL}^{-1}$ cause an intermediate inhibition in biogas production (within 33-50\%). In biofilm systems, the original wastewater biofilms are highly tolerant to $\mathrm{Ag}$ NPs. With the application of $200 \mathrm{mg} \mathrm{L}^{-1} \mathrm{Ag}$ NPs, the reduction in biofilm bacteria measured by heterotrophic plate counts is insignificant after $24 \mathrm{~h}$. However, after the removal of loosely bound EPS, the viability of wastewater biofilms is reduced when treated under the same conditions. ${ }^{78}$

Most of the results indicate that low concentrations of $\mathrm{Ag}$ NPs (e.g. , <2 $\left.\mathrm{mg} \mathrm{L}^{-1}\right)$ do not have significant effects on nitrogen removal in activated sludge systems. However, Ag NPs only have a mild impact on $\mathrm{NH}_{4}{ }^{+}-\mathrm{N}$ removal, but the denitrificationrelated species are inhibited by $0.5 \mathrm{mg} \mathrm{L}^{-1} \mathrm{Ag}$ NPs, including Diaphorobacter species, Thauera species and those in the Sphaerotilus-Leptothrix group. ${ }^{79} \mathrm{Ag}$ NPs at concentrations $>2 \mathrm{mg}$ $\mathrm{L}^{-1}$ disrupt ammonia removal in activated sludge in an SBR, while Ag-ligand formation and microbial adaptation (chloride or sulphide groups) can reduce their overall impacts. ${ }^{80}$ When the concentration reaches $2 \mathrm{mg} \mathrm{L}^{-1}$ of total $\mathrm{Ag}$, biological nutrient removal can be disrupted, whereas Ag NPs do not exhibit a significant effect on ammonia removal during a $2 \mathrm{mg}$ $\mathrm{L}^{-1}$ spike. However, nitrification recovers quickly, especially at lower concentrations of $\mathrm{Ag}$ NPs. In addition, Doolette et al. ${ }^{\mathbf{8 1}}$ also suggested that the nitrification rate is not affected by $\mathrm{Ag}$ NPs at the concentration of $2.5 \mathrm{mg} \mathrm{L}^{-1}$ in an SBR. Ag NPs are found to be transformed into $\mathrm{Ag}_{2} \mathrm{~S}$ in activated sludge, and $\mathrm{Ag}_{2} \mathrm{~S}$ has no adverse effects on nitrification. However, a change in niche populations occur in aerobic sludge, indicating Ag NPs can negatively affect sub-dominant wastewater microbial communities.

Additionally, ${ }^{82}$ the continuous loading of Ag NPs $\left(0.1 \mathrm{mg} \mathrm{L}^{-1}\right)$ for more than $60 \mathrm{~d}$ does not show adverse impacts on bacterial activity in a membrane bioreactor (MBR) activated sludge system. The nitrifying bacterial community structure is stable after long-term exposure to Ag NPs, while an abundance of the silver resistance gene sile in the MBR is increased after 41 $\mathrm{d}$ exposure, and then decreased with continuous exposure. These two results above indicate that activated sludge can effectively reduce the toxicity of Ag NPs by microbial adaptation and adsorbing or precipitating Ag NPs.

In summary, low concentrations of $\mathrm{Ag}$ NPs $\left(<2 \mathrm{mg} \mathrm{L}^{-1}\right)$ mostly do not have significant effects on nitrification and denitrification in conventional activated sludge systems, while 
$\mathrm{Ag}$ NPs at high concentrations $\left(>2 \mathrm{mg} \mathrm{L}^{-1}\right)$ can mostly inhibit nitrogen removal with long-term exposure.

Compared with Ag NPs, only a small number of studies have been conducted on the impact of $\mathrm{Cu}$ NPs on activated sludge. At concentrations from 0.1 to $10 \mathrm{mg} \mathrm{L^{-1 }}$, TN removal is promoted (improved from $60.6 \%$ to $>70 \%$ ) and $\mathrm{N}_{2} \mathrm{O}$ generation is reduced, but ammonia removal is not affected..$^{83}$ It was found that most $\mathrm{Cu}$ NPs are absorbed onto activated sludge, but the activated sludge surface is not damaged. The released $\mathrm{Cu}^{2+}$ is the main cause of TN removal improvement and $\mathrm{N}_{2} \mathrm{O}$ reduction.

It was also found that the activities of ammonia monooxygenase and nitrite oxidoreductase are not affected by $\mathrm{Cu}$ NPs, whereas the activities of denitrification enzymes are increased, and $\mathrm{Cu}$ NPs increase the number of denitrifiers but decrease nitrite accumulation. All these results are in correspondence with the enhancement of TN removal and the decrease in $\mathrm{N}_{2} \mathrm{O}$ production. Overall, Cu NPs do not show much of a negative impact on biological nitrogen removal. Short-term exposure to $\mathrm{Cu}$ NPs causes slight toxicity to ammonia oxidizing bacteria, but TN removal is promoted and $\mathrm{N}_{2} \mathrm{O}$ generation is reduced by long-term exposure at certain concentrations of $\mathrm{Cu}$ NPs.

Several studies reveal the impacts of ZnO NPs on nitrification and denitrification. For example, short-term exposure to $\mathrm{ZnO}$ NPs can decrease TN removal from $81.5 \%$ to $75.6 \%$ and $70.8 \%$, respectively, at the concentrations of 10 and $50 \mathrm{mg} \mathrm{L}^{-1} \cdot{ }^{84}$ It was suggested that the inhibition of nitrogen removal mainly results from the release of $\mathrm{Zn}^{2+}$ from $\mathrm{ZnO}$ NPs dissolution and the increase of ROS production, which decreases nitrate reductase (NAR) activity. Similarly, the denitrification-related species were inhibited by $5 \mathrm{mg} \mathrm{L}^{-1} \mathrm{ZnO}$ NPs, including Diaphorobacter species, Thauera species and those in the Sphaerotilus-Leptothrix group, although the $\mathrm{NH}_{4}{ }^{+}-\mathrm{N}$ removal efficiency was either slightly reduced or not reduced at all. ${ }^{85}$ In addition, ZnO NPs slightly decrease TN removal efficiency and reduce $\mathrm{NH}_{4}{ }^{+} \mathrm{N}$ removal by inhibiting the respiration of nitrifying microorganisms. ${ }^{86}$ Overall, ZnO NPs affect TN removal efficiency by inhibiting the activity of NAR and the denitrification related to bacteria.

Several reports have described the impact of $\mathrm{TiO}_{2} \mathrm{NPs}$ on nitrification and denitrification. The concentrations of 1 and $50 \mathrm{mg} \mathrm{L}{ }^{-1} \mathrm{TiO}_{2}$ NPs do not have acute effects on wastewater nitrogen removal after short-term exposure $(1 \mathrm{~d})$ in an anaerobic-low dissolved oxygen SBR, whereas $50 \mathrm{mg} \mathrm{L}{ }^{-1} \mathrm{TiO}_{2}$ NPs significantly decreases TN removal efficiency by $56 \%$ after $70 \mathrm{~d}$ exposure. Mechanism analysis reveals that $\mathrm{TiO}_{2} \mathrm{NPs}$ at $50 \mathrm{mg} \mathrm{L}^{-1}$ obviously reduces the abundance of nitrifying bacteria and the diversity of microbial communities in activated sludge. In particular, ammonia-oxidizing bacteria are greatly decreased after long-term exposure to $50 \mathrm{mg} \mathrm{L^{-1 }} \mathrm{TiO}_{2} \mathrm{NPs}_{\text {, }}$ resulting from the serious deterioration of ammonia oxidation. In addition, $\mathrm{TiO}_{2} \mathrm{NPs}$ at $50 \mathrm{mg} \mathrm{L}^{-1}$ can inhibit the activities of ammonia monooxygenase (AMO) and nitrite oxidoreductase (NOR) after long-term exposure. ${ }^{87} \mathrm{TiO}_{2}$ NPs reduce the microbial diversity in activated sludge at concentrations from $100 \mathrm{mg}$ $\mathrm{L}^{-1}$ to $200 \mathrm{mg} \mathrm{L}^{-1}$, and the abundance of denitrifying bacteria is obviously decreased, which explains the inhibition.
Summarily, exposure time is one of the important factors of the adverse effects of $\mathrm{TiO}_{2}$ NPs. Low concentrations $(e . g .<50 \mathrm{mg}$ $\mathrm{L}^{-1}$ ) of $\mathrm{TiO}_{2}$ NPs do not have acute effects on wastewater nitrogen removal after short-term exposure, but high concentrations (e.g. 100-200 mg L L ${ }^{-1}$ ) of $\mathrm{TiO}_{2}$ NPs can markedly decrease TN removal efficiency. Different from short-term exposure, $50 \mathrm{mg} \mathrm{L}{ }^{-1} \mathrm{TiO}_{2}$ NPs can significantly decrease TN removal efficiency after long-term exposure. $\mathrm{TiO}_{2}$ NPs inhibit both nitrifying bacteria and denitrifying bacteria, as well as AMO and NOR.

Only a small number of reports are found on the impact of $\mathrm{Al}_{2} \mathrm{O}_{3}$ NPs on wastewater nitrogen removal. Most of the $\mathrm{Al}_{2} \mathrm{O}_{3}$ NPs can adsorb onto activated sludge, but $\mathrm{Al}_{2} \mathrm{O}_{3}$ NPs have no adverse effects on the surface integrity and viability of activated sludge. ${ }^{88}$ Additionally, short-term exposure to $\mathrm{Al}_{2} \mathrm{O}_{3}$ NPs does not present adverse impacts on wastewater nitrification and denitrification. However, the long-term exposure to $50 \mathrm{mg} \mathrm{L}^{-1}$ $\mathrm{Al}_{2} \mathrm{O}_{3}$ NPs can decrease the TN removal efficiency by $17.9 \%$, owing to a suppressed denitrification process. The abundance of denitrifying bacteria is also decreased, and the activities of key denitrifying enzymes, such as nitrite reductase (NIR), are inhibited. Therefore, only long-term exposure to $\mathrm{Al}_{2} \mathrm{O}_{3} \mathrm{NPs}$ has adverse impacts on wastewater nitrification and denitrification.

The acute and chronic effect of $\mathrm{SiO}_{2}$ NPs on the nutrient removal performance of activated sludge was reported. Zheng et $a l .{ }^{89}$ noted that the presence of $\mathrm{SiO}_{2}$ NPs at an environmentally relevant concentration (e.g. $1 \mathrm{mg} \mathrm{L}^{-1}$ ) caused no adverse acute and chronic effects on sludge viability and wastewater nitrogen removal. Nevertheless, long-term exposure to $50 \mathrm{mg}$ $\mathrm{L}^{-1} \mathrm{SiO}_{2}$ NPs can depress the TN removal efficiency by $18 \%$ after $70 \mathrm{~d}$ exposure, resulting from the declined activities of denitrifying enzymes and NIR. Further research revealed that the microbial community structure is changed, and the abundance of denitrifying bacteria is reduced after chronic exposure. In summary, $\mathrm{SiO}_{2}$ NPs at low concentrations cause no significant adverse effects on nitrogen removal, but high concentrations of $\mathrm{SiO}_{2}$ NPs affect TN removal efficiency.

We identified two reports regarding the most widely used magnetic NPs (nZVI, magnetite $\left(\mathrm{Fe}_{3} \mathrm{O}_{4}\right)$ and maghemite $(\gamma$ $\left.\left.\mathrm{Fe}_{2} \mathrm{O}_{3}\right) \mathrm{NPs}\right)$. Wu et al. ${ }^{90}$ examined the impacts of nZVI on nitrogen removal under continuous aerobic/anaerobic conditions in an activated sludge system and found no measurable effect of nZVI on nitrogen removal at the concentrations of $50 \mathrm{mg} \mathrm{\textrm {L } ^ { - 1 }}$ and below. However, $200 \mathrm{mg} \mathrm{L}^{-1}$ of nZVI inhibited $\mathrm{NH}_{4}{ }^{+}-\mathrm{N}$ removal. The microbial activities were inhibited on exposure to $\mathrm{nZVI}$; the adenosine triphosphate (ATP) content was decreased by approximately $13 \%, 31 \%$ and $43 \%$ at the nZVI concentrations of 20,50 , and $200 \mathrm{mg} \mathrm{L}^{-1}$, respectively; and ROS production was increased. Lower concentrations of nZVI (20 and $50 \mathrm{mg} \mathrm{L}^{-1}$ ) boosted the microbial activity, whereas $200 \mathrm{mg}$ $\mathrm{L}^{-1}$ nZVI caused an approximate $19 \%$ depression in dehydrogenase activity. In addition, the acute exposure to 50-200 mg $\mathrm{L}^{-1} \mathrm{Fe}_{3} \mathrm{O}_{4}$ NPs can decrease $\mathrm{TN}$ removal efficiencies, resulting from the inhibition of nitrifying bacteria and the secretion of EPS. ${ }^{91}$ In contrast, chronic exposure to $50 \mathrm{mg} \mathrm{L}^{-1}$ magnetic NPs can clearly improve $\mathrm{TN}$ removal, resulting from the increased abundance of nitrifying bacteria and the improved activities of 
Table 2 Summary of effects of NPs on biological treatment of municipal wastewater

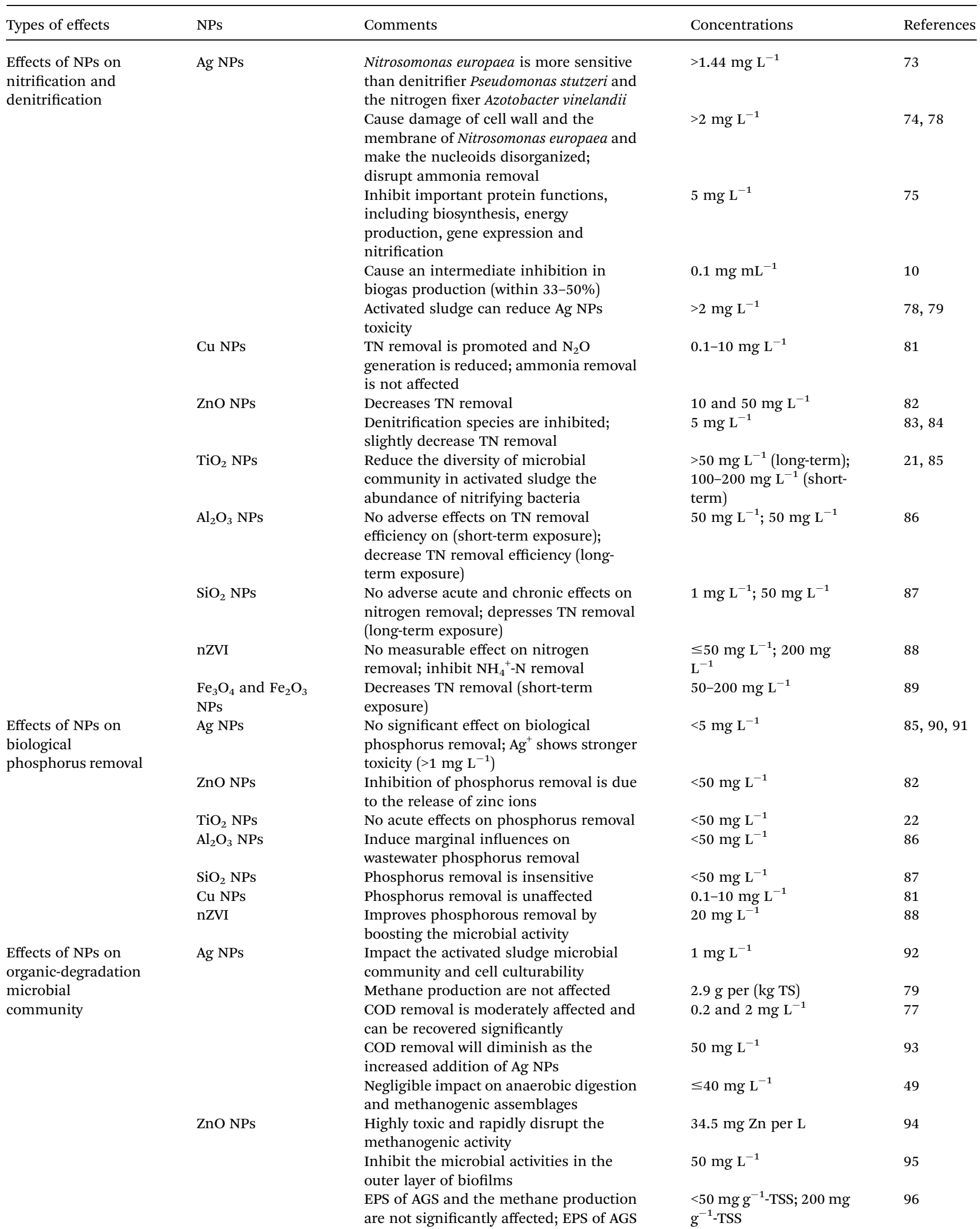
and the methane production are decreased 
Table 2 (Contd.)

\begin{tabular}{|c|c|c|c|c|}
\hline & CuO NPs & $\begin{array}{l}\text { Marked negative effect on the } \\
\text { performance of methanogenesis in UASB } \\
\text { reactor }\end{array}$ & $1.4 \mathrm{mg} \mathrm{Cu}$ per $\mathrm{L}$ & 99 \\
\hline & $\mathrm{Cu}$ NPs & $\begin{array}{l}\text { Cause inhibition of acetoclastic } \\
\text { methanogens but not } \mathrm{H}_{2} \text {-utilizing } \\
\text { methanogens }\end{array}$ & $62 \mathrm{mg} \mathrm{L}^{-1}$ & 97 \\
\hline & $\mathrm{SiO}_{2} \mathrm{NPs}$ & $\begin{array}{l}\text { Affect the biological activity in activated } \\
\text { sludge through the inhibition of total } \\
\text { oxygen uptake }\end{array}$ & $>50 \mathrm{mg} \mathrm{L}^{-1}$ & 101 \\
\hline
\end{tabular}

NAR and NIR. The release of iron ions from the dissolution of magnetic NPs may also be responsible for the increase in bacteria activities. In summary, magnetic NPs have little adverse effects on nitrification and denitrification at $\leq 50 \mathrm{mg}$ $\mathrm{L}^{-1}$ of magnetic NPs, whereas high concentrations of NPs can cause a depression in dehydrogenase activity.

Overall, exposure time (short-term or long-term) is one of the important factors affecting the adverse effects of many types of NPs. The adverse effects of many types of NPs are of concern for the nitrification and denitrification in activated sludge. Most NPs at certain concentrations exhibit some adverse effects on nitrogen removal by inhibiting the key enzymes of nitrifying and denitrifying bacteria. Some adverse effects result from the release of ions from dissolved NPs.

\subsection{Effects of NPs on biological phosphorus removal}

Some studies have been reported on the effects of NPs on biological phosphorus removal. It was reported ${ }^{92}$ that $\mathrm{Ag}$ NPs $\left(<5 \mathrm{mg} \mathrm{L}^{-1}\right)$ do not present obvious effects on biological phosphorus removal in both acute and chronic exposure. However, the removal rate of phosphorus was decreased to $48.8 \%$ at $1 \mathrm{mg}$ $\mathrm{L}^{-1}$ of $\mathrm{Ag}^{+}$at short-term exposure, and almost zero phosphorus removal was achieved when the concentration of $\mathrm{Ag}^{+}$was greater than $2 \mathrm{mg} \mathrm{L}^{-1}$. $\mathrm{Ag}^{+}$shows stronger toxicity to polyphosphate accumulating organisms (PAOs) than glycogen accumulating organisms (GAOs). In addition, the decrease in anaerobic phosphorus release by $\mathrm{Ag}^{+}$is caused by the inhibition of the activities of adenylate kinase and exopolyphosphatase (PPX), whereas the decrease in aerobic phosphorus uptake is due to the suppression of energy generation for phosphorus uptake. A comparison was conducted on the effects of Ag NPs and $\mathrm{Ag}^{+}$at concentrations from 1 to $5 \mathrm{mg} \mathrm{L}^{-1}$ on the performance of enhanced biological phosphorus removal (EBPR). Ag NPs showed no obvious effect on EBPR at both acute and chronic exposure, ${ }^{93}$ whereas phosphorus removal was decreased by a sudden increase in $\mathrm{Ag}^{+}$concentration and was gradually recovered after long-term culture. The mechanism study showed that the transformation of polyhydroxyalkanoates (PHA) and glycogen, and the activity of PPX decline when $\mathrm{Ag}^{+}$ was suddenly increased, but they were recovered after long-term culture. $^{82}$

The effects of NPs such as $\mathrm{ZnO}, \mathrm{TiO}_{2}, \mathrm{Al}_{2} \mathrm{O}_{3}$, and $\mathrm{SiO}_{2} \mathrm{NPs}$ on biological phosphorus removal are of concern. ZnO NPs at concentrations of 10 and $50 \mathrm{mg} \mathrm{L}^{-1}$ can inhibit phosphorus removal and the inhibition result from the release of zinc ions from ZnO NPs dissolution, as well as ROS production, causing an inhibitory effect on PAOs and decreased activities of PPX and polyphosphate kinase (PPK).$^{84}$ It was reported that 1 and $50 \mathrm{mg}$ $\mathrm{L}^{-1} \mathrm{TiO}_{2}$ NPs do not exhibit significant impacts on phosphorus removal at both acute exposures $(1 \mathrm{~d})$ and chronic exposure (70 d). ${ }^{22}$ Short-term exposure to 1 and $50 \mathrm{mg} \mathrm{L}{ }^{-1} \mathrm{Al}_{2} \mathrm{O}_{3}$ NPs can induce marginal influence on wastewater phosphorus removal. ${ }^{88}$ In addition, transformations of intracellular PHA and glycogen were not significantly changed in the presence of 1 and $50 \mathrm{mg} \mathrm{L}^{-1} \mathrm{Al}_{2} \mathrm{O}_{3}$ NPs.

Zheng et al. reported that wastewater phosphorus removal is insensitive to 1 and $50 \mathrm{mg} \mathrm{L}{ }^{-1} \mathrm{SiO}_{2}$ NPs at both acute and chronic exposures because the important factors related to phosphorus removal, such as the activities of PPX and PPK and the intracellular transformations of PHA and glycogen, were not obviously changed. ${ }^{89}$ As illustrated above, ${ }^{83}$ the presence of $\mathrm{Cu}$ NPs in activated sludge affects the nitrogen removal by increasing the activity of NAR and NIR while the effects of $\mathrm{Cu}$ NPs are insignificant on the activities of AMO, NOR, PPX, and PPK. This means that phosphorus removal is unaffected by $\mathrm{Cu}$ NPs. ${ }^{83}$ As illustrated above, ${ }^{90}$ nZVI does not exhibit any measurable influence on nitrogen removal at $50 \mathrm{mg} \mathrm{L}^{-1}$ and below, whereas the addition of nZVI at $10-20 \mathrm{mg} \mathrm{L}^{-1}$ significantly improves phosphorous removal by boosting microbial activity. ${ }^{90}$

In summary, the inhibition of phosphorus removal induced by ZnO NPs is due to the release of zinc ions from ZnO NPs dissolution, as well as ROS production. Most other NPs, such as $\mathrm{Cu}$ NPs, $\mathrm{TiO}_{2}$ NPs, $\mathrm{Al}_{2} \mathrm{O}_{3}$ NPs and $\mathrm{SiO}_{2}$ NPs, do not present significantly adverse effects on biological phosphorus removal at the concentrations of $50 \mathrm{mg} \mathrm{L}^{-1}$ and below, because they have no significant impacts on the activities of PPX and PPK, and the transformations of intracellular PHA and glycogen. Low 
concentrations of nZVI (10-20 $\left.\mathrm{mg} \mathrm{L}^{-1}\right)$ can improve phosphorous removal.

\subsection{Effects of NPs on organic-degradation microbial communities}

Many studies have commenced investigations into the effects of NPs on activated sludge microbial communities. Ag NPs $(1 \mathrm{mg}$ $\mathrm{L}^{-1}$ ) can affect activated sludge microbial communities and cell culturability depending on the physical structure of the activated sludge flocs, the spatial distribution of microorganisms in activated sludge flocs, and the community structures in the activated sludge. ${ }^{94}$ Doolette et al. ${ }^{81}$ found methane production was not affected by Ag NPs $\left(\sim 3 \mathrm{~g} \mathrm{~kg}^{-1}\right.$-TS $)$ in an anaerobic batch test. $\mathrm{Ag}$ NPs were found to be transformed into $\mathrm{Ag}_{2} \mathrm{~S}$ in activated sludge, and transformed Ag NPs have no adverse effects on methanogenesis. However, a change in niche populations was found, suggesting that Ag NPs may adversely impact sub-dominant wastewater microbial communities. In addition, Chen et al. ${ }^{79}$ suggested that COD removal is moderately affected by low concentrations of Ag NPs. When Ag NPs were added at 0.2 and $2 \mathrm{mg} \mathrm{L}^{-1}$, the removal percentages were decreased from $99 \%$ to approximately $80 \%$, but COD removal was remarkably recovered $3 \mathrm{~d}$ later, and a COD removal efficiency of approximately $93 \%$ was achieved. Additionally, a remarkable change occurred in the microbial community structure, which can be interpreted as an improvement in recovery. However, it was reported that the COD removal rate will decrease with the increased addition of Ag NPs and that only $20 \%$ of COD is removed at an Ag NPs concentration of $50 \mathrm{mg} \mathrm{L}^{-1}$. $^{95}$ Yang et al. suggested that $\mathrm{Ag}$ NPs at moderate concentrations ( $\leq 40 \mathrm{mg} \mathrm{L}^{-1}$ ) have negligible effects on anaerobic digestion and methanogenic assemblages, ${ }^{49}$ whereas $50 \mathrm{mg} \mathrm{L}^{-1}$ Ag NPs significantly decreased the COD removal efficiency.

ZnO NPs at $34.5 \mathrm{mg} \mathrm{L}^{-1}$ are highly toxic and rapidly disrupt the methanogenic activity during UASB operation, and the toxicity was more severe for acetoclastic methanogens compared with hydrogenotrophic methanogens. ${ }^{96}$ In addition, sub-ppm levels of ZnO NPs present a remarkable effect over the long-term, as evidenced by the gradual decrease in the methanogenic activity of the biomass. This finding may be attributable to two factors: the enhanced toxicity with exposure time, and the accumulation of ZnO NPs during wastewater treatment that may increase the effective concentration of ZnO NPs in direct contact with the microorganisms in sludge. Also, $50 \mathrm{mg}$ $\mathrm{L}^{-1}$ ZnO NPs can inhibit the microbial activities only in the outer layer of biofilms, and bacteria present in the deeper parts of biofilms become even more active. ${ }^{97}$ Methane production was not obviously affected by ZnO NPs at the concentrations of 10 and $50 \mathrm{mg} \mathrm{g}^{-1}$-TSS, but it was decreased when ZnO NPs concentration was higher than $100 \mathrm{mg} \mathrm{g}^{-1}$-TSS, because ZnO NPs caused a decrease of proteins in EPS by $69.6 \% .{ }^{98}$ Additionally, the $\mathrm{C}-\mathrm{O}-\mathrm{C}$ group of polysaccharides and carboxyl group of proteins in EPS were also changed. The average methane production was decreased by $43.5 \%$ at a ZnO NPs concentration of $200 \mathrm{mg} \mathrm{g}^{-1}$-TSS. ZnO NPs can also cause severe inhibition of methanization.
$\mathrm{Cu}$ NPs can cause inhibition of acetoclastic methanogens, but not of $\mathrm{H}_{2}$-utilizing methanogens at a $\mathrm{Cu}$ NPs concentration of $62 \mathrm{mg} \mathrm{L}^{-1} .{ }^{99}$ Therefore, ZnO NPs, CuO NPs and Cu NPs can induce inhibition of methane production during anaerobic biological wastewater processes. The production of ROS and the release of LDH showed that exposing the activated sludge to CuO NPs caused oxidative stress and damaged cell membranes in the sludge flocs and the production of EPS; in particular, polysaccharides were enhanced by $89.7 \%$ with exposure to $50 \mathrm{mg} \mathrm{L}{ }^{-1} \mathrm{CuO}$ NPs. ${ }^{100}$ Long-term exposure of the microorganisms retained in the sludge bed to CuO NPs $(1.4 \mathrm{mg} \mathrm{Cu}$ per L) can cause significant inhibition of Acetoclastic methanogenesis, which eventually leads to the complete disruption of the bioreactor performance. ${ }^{101}$ The inhibition is likely induced by both CuO NPs and released copper ions.

The addition of $\mathrm{Cu}$ NPs to biological wastewater treatment systems presented no significant effects on sludge fermentative volatile fatty acids (VFA), the preferred carbon source for wastewater biological nutrient removal production, as the sludge solubilization was increased, and the acidification was decreased.$^{102}$ When Cu NPs are directly added to the anaerobic fermentation reactor, both the hydrolysis and acidification are inhibited at a $\mathrm{Cu}$ NPs concentration of $50 \mathrm{mg} \mathrm{L}^{-1}$, resulting in an ultimate VFA production much less than that of the control by approximately $45 \%$ after $10 \mathrm{~d}$ exposure.

The adverse impacts of $\mathrm{SiO}_{2}$ NPs on activated sludge was studied using the activated sludge respiration inhibition test and it was suggested that $\mathrm{SiO}_{2}$ NPs affect the biological activity in activated sludge through the inhibition of total oxygen uptake at concentrations higher than $50 \mathrm{mg} \mathrm{L}^{-1}{ }^{103}$ Transmission Electron Microscopy (TEM) image analysis suggests some of the $\mathrm{SiO}_{2}$ NPs are adsorbed on and/or apparently embedded in the microbial cell membrane.

Summarily, most NPs at certain concentrations have adverse effects on microorganisms for organic degradation in activated sludge (Table 2). After exposure, a degree of inhibition might occur to microbial communities and to the activities of certain key enzymes in activated sludge, subsequently resulting in the abnormal performance of activated sludge systems.

\section{Conclusions and future directions}

Many studies have been conducted on the fate of NPs, as well as their effects on biological wastewater treatment, and many achievements have been reported. It can be concluded from this review as follows:

(1) Most NPs, such as Ag, $\mathrm{ZnO}, \mathrm{CuO}, \mathrm{Al}_{2} \mathrm{O}_{3}, \mathrm{SiO}_{2}$, CNTs and magnetic NPs, can cause varying degrees of damage to microorganisms at certain concentrations. $\mathrm{Ag}, \mathrm{Cu}$ and $\mathrm{ZnO}$ NPs present relatively significant toxic effects compared with other NPs at similar exposure concentrations. In particular, $\mathrm{TiO}_{2} \mathrm{NPs}$ do not show strong toxicity to microorganisms at both shortterm (even at $500 \mathrm{mg} \mathrm{L}^{-1}$ ) and long-term exposures $(<50 \mathrm{mg}$ $\left.\mathrm{L}^{-1}\right)$.

(2) WWTPs operated using activated sludge have the potential to remove most types of NPs, such as $\mathrm{Ag}, \mathrm{Cu}, \mathrm{ZnO}, \mathrm{CuO}$, and $\mathrm{TiO}_{2}$, but not $\mathrm{SiO}_{2}$, by interaction with biomass. Ag NPs, Cu NPs 
and $\mathrm{ZnO}$ NPs can be partially transformed into $\mathrm{Ag}^{+}, \mathrm{Cu}^{2+}$ and $\mathrm{Zn}^{2+}$, respectively, under certain conditions. The poor removal of $\mathrm{SiO}_{2} \mathrm{NPs}$ is due to the high colloidal stability of $\mathrm{SiO}_{2} \mathrm{NPs}$ in the wastewater and their limited propensity to biosorption.

(3) Most NPs have varying degrees of impacts on the performance of the biological treatment of wastewater, including nitrogen, phosphorus and organic pollutants removal. The impacts are dose-dependent under most conditions, and the exposure time (short-term or long-term) is also an important factor of adverse effects. (a) For nitrogen removal, Ag, $\mathrm{CuO}$ and $\mathrm{ZnO}$ NPs have slight or moderate effects on TN removal at relatively low concentrations; $\mathrm{TiO}_{2}$ NPs show some inhibitory effects on nitrifying and denitrifying bacteria, and AMO and NOR; and $\mathrm{Al}_{2} \mathrm{O}_{3}$ and $\mathrm{SiO}_{2}$ NPs have adverse impacts on nitrification and denitrification. (b) For phosphorus removal, $\mathrm{Al}_{2} \mathrm{O}_{3}, \mathrm{TiO}_{2}$ and $\mathrm{SiO}_{2}$ NPs do not have significant adverse effects, but ZnO NPs can result in net phosphorus removal failure at certain concentrations. (c) For organics removal, Ag NPs can decrease COD removal. ZnO NPs and CuO NPs can inhibit methane production during anaerobic biological wastewater processes. On the whole, the impacts are dosedependent under most conditions. Some of the impacts are due to the NPs themselves, and some of impacts result from released ions such as $\mathrm{Ag}^{+}, \mathrm{Cu}^{2+}$, and $\mathrm{Zn}^{2+}$.

Although many studies have been conducted in this field, the achievements are far from complete. For instance, as to Au NPs and CNTs, no reports are found on their effects on biological nitrogen and phosphorus removal. There are only a few studies found that report the effects of NPs on organics removal. NPs removed from sewage will accumulate in biosolids, and more research is required to understand the fate of NPs upon the ultimate disposal of biosolids. The effects of NPs on biosolids disposal process also need more research. In addition, longterm effects of NPs at low concentrations on the functional microorganisms need more concern.

\section{Acknowledgements}

The Project is sponsored by the Scientific Research Foundation for the Returned Overseas Chinese Scholars, State Education Ministry, China. This work is also supported by the Key Laboratory of Urban Water Resource and Environment of Harbin institute of technology, China (ES201608).

\section{References}

1 Y. Ju-Nam and J. R. Lead, Manufactured nanoparticles: An overview of their chemistry, interactions and potential environmental implications, Sci. Total Environ., 2008, 400, 396-414.

2 J. Wackerlig and R. Schirhagl, Applications of Molecularly Imprinted Polymer Nanoparticles and their Advances toward Industrial Use: A Review, Anal. Chem., 2016, 88(1), 250-261.

3 S. J. Klaine, P. J. J. Alvarez, G. E. Batley, T. F. Fernandes, R. D. Handy, D. Y. Lyon, S. Mahendra, M. J. McLaughlin and J. R. Lead, Nanomaterials in the environment:
Behavior, fate, bioavailability, and effects, Environ. Toxicol. Chem., 2008, 27(9), 1825-1851.

4 S. K. Brar, M. Verma, R. D. Tyagi and R. Y. Surampalli, Engineered nanoparticles in wastewater and wastewater sludge - Evidence and impacts, Waste Manag., 2010, 30, 504-520.

5 V. K. Sharma, K. M. Siskova, R. Zboril and J. L. GardeaTorresdey, Organic-coated silver nanoparticles in biological and environmental conditions: Fate, stability and toxicity, Adv. Colloid Interface Sci., 2014, 204, 15-34.

6 L. A. S. Bahari and H. Hamishehkar, The impact of variables on particle size of solid lipid nanoparticles and nanostructured lipid carriers: A comparative literature review, Adv. Pharm. Bull., 2016, 6(2), 143-151.

7 B. Song, J. Liu, X. L. Feng, et al., A review on potential neurotoxicity of titanium dioxide nanoparticles, Nanoscale Res. Lett., 2015, 10, 342-358.

8 A. Lazareva and A. A. Keller, Estimating Potential Life Cycle Releases of Engineered Nanomaterials from Wastewater Treatment Plants, ACS Sustainable Chem. Eng., 2014, 2, 1656-1665.

9 A. A. Keller and A. Lazareva, Predicted Releases of Engineered Nanomaterials: From Global to Regional to Local, Environ. Sci. Technol. Lett., 2014, 1, 65-70.

10 L. S. Dorobantu, C. Fallone, A. J. Noble, J. Veinot, G. Ma, G. G. Goss and R. E. Burrel, Toxicity of silver nanoparticles against bacteria, yeast, and algae, $J$. Nanopart. Res., 2015, 17, 172-184.

11 A. García, L. Delgado, J. A. Torà, E. Casals, E. González, V. Puntes, X. Font, J. Carrera and A. Sánchez, Effect of cerium dioxide, titanium dioxide, silver, and gold nanoparticles on the activity of microbial communities intended in wastewater treatment, J. Hazard. Mater., 2012, 199-200, 64-72.

12 A. Gitipour, S. W. Thiel, K. G. Scheckel and T. Tolaymat, Anaerobic toxicity of cationic silver nanoparticles, Sci. Total Environ., 2016, 557-558, 363-368.

13 A. Ivask, I. Kurvet, K. Kasemets, et al., Size-dependent toxicity of silver nanoparticles to bacteria, yeast, algae, crustaceans and mammalian cells in vitro, PLoS One, 2014, 9(7), e102108.

14 S.-W. Lee, S.-Y. Park, Y. H. Kim, H. Im and J. Choi, Sci. Total Environ., 2016, 553, 565-573.

15 L. K. Adams, D. Y. Lyon and P. J. J. Alvarez, Water Res., 2006, 40, 3527-3532.

16 R. Brayner, R. Ferrari-Iliou, N. Brivois, S. Djediat, M. F. Benedetti and F. Fiévet, Nano Lett., 2006, 6, 866-870.

17 S. Wang, M. C. Gao, Z. L. She, D. Zheng, C. J. Jin, L. Guo, Y. G. Zhao, Z. W. Li and X. J. Wang, Bioresour. Technol., 2016, 216, 428-436.

18 F. Gottschalk, T. Sonderer, R. W. Scholz and B. Nowack, Environ. Sci. Technol., 2009, 43, 9216-9222.

19 L. K. Adams, D. Y. Lyon and P. J. J. Alvarez, Water Res., 2006, 40, 3527-3532.

20 T. J. Battin, F. V. D. Kammer, A. Weilhartner, S. Ottofuelling and T. Hofmann, Environ. Sci. Technol., 2009, 43, 80988104. 
21 C. Supha, Y. Boonto, M. Jindakaraked, J. Ananpattarachai and P. Kajitvichyanukul, Sci. Technol. Adv. Mater., 2015, 16, 1-12.

22 X. Zheng, Y. Chen and R. Wu, Environ. Sci. Technol., 2011, 45, 7284-7290.

23 Y. L. Su, Y. G. Chen and X. Zheng, Water Res., 2016, 99, 216224.

24 J. Zhao, Z. Wang, Y. Dai and B. Xing, Water Res., 2013, 47(12), 4169-4178.

25 W. Jiang, H. Mashayekhi and B. Xing, Environ. Pollut., 2009, 157, 1619-1625.

26 I. M. Sadiq, B. Chowdhury, N. Chandrasekaran and A. Mukherjee, Biol. Med., 2009, 5, 282-286.

27 S. Pakrashi, S. Dalai, D. Sabat, S. Singh, N. Chandrasekaran and A. Mukherjee, Chem. Res. Toxicol., 2011, 24, 1899-1904.

28 M. A. Ansari, H. M. Khan and A. A. Khan, J. Appl. Microbiol., 2014, 116(4), 772-783.

29 T. J. Brunner, P. Wick, P. Manser, P. Spohn, R. N. Grass, L. K. Limbach, A. Bruinink and W. J. Stark, Environ. Sci. Technol., 2006, 40, 4374-4381.

30 J. Chang, K. L. B. Chang, D. Hwang and Z. Kong, Environ. Sci. Technol., 2007, 41, 2064-2068.

31 I. O. Skorochod, A. O. Roy and I. K. Kurdish, Nanoscale Res. Lett., 2016, 11, 139-144.

32 A. Besinis, T. D. Peralta and R. D. Handy, Nanotoxicology, 2014, 8(1), 1-16.

33 M. Stefaniuk, P. Oleszczuk and Y. Sik Ok, Chem. Eng. J., 2016, 287, 618-632.

34 M. P. Herrling, S. Lackner, O. Tatti, G. Guthausen, M. Delay, M. Franzreb and H. Horn, Sci. Total Environ., 2016, 544, 722-729.

35 C. Lee, J. Y. Kim, W. I. Lee, K. L. Nelson, J. Yoon and D. L. Sedlak, Environ. Sci. Technol., 2008, 42, 4927-4933.

36 M. Diao and M. Yao, Water Res., 2009, 43, 5243-5251.

37 Z. Xiu, Z. Jin, T. Li, S. Mahendra, G. V. Lowry and P. J. J. Alvarez, Iron particles on a mixed culture, Bioresour. Technol., 2010, 101, 1141-1146.

38 D. Kerfahi, B. M. Tripathi, D. Singh, H. Kim, S. Lee, J. Lee and J. M. Adams, PLoS One, 2015, 10, e0123042.

39 P. Oleszczuk, I. Jośko and B. Xing, J. Hazard. Mater., 2011, 186, 436-442.

40 D. Goyal, X. J. Zhang and J. N. Rooney-Varga, Lett. Appl. Microbiol., 2010, 51, 428-435.

41 L. A. Luongo and X. Zhang, J. Hazard. Mater., 2010, 178, 356-362.

42 R. J. Narayan, C. J. Berry and R. L. Brigmon, Mater. Sci. Eng., $B, 2005,123,123-129$.

43 S. Kang, M. Herzberg, D. F. Rodrigues and M. Elimelech, Langmuir, 2008, 24, 6409-6413.

44 T. T. A. Le, J. McEvoy and E. Khan, Sci. Total Environ., 2016, 565, 787-794.

45 Y. Y. Qu, X. W. Zhang, W. L. Shen, et al., Bioresour. Technol., 2016, 211, 209-215.

46 T. Yadav, A. A. Mungray and A. K. Mungray, Environ. Sci. Pollut. Res., 2016, 23, 4063-4072.

47 H. Mu, Y. Chen and N. Xiao, Bioresour. Technol., 2011, 102, 10305-10311.
48 H. Mu and Y. Chen, Water Res., 2011, 45, 5612-5620.

49 Y. Yang, Q. Chen, J. D. Wall and Z. Hu, Water Res., 2012, 46, 1176-1184.

50 H. Park, H. Y. Kim, S. Cha, C. H. Ahn, J. Roh, S. Park, S. Kim, K. Choi, J. Yi, Y. Kim and J. Yoon, Chemosphere, 2013, 92, 524-528.

51 E. F. C. Chaúque, J. N. Zvimba, J. C. Ngila and N. Musee, Phys. Chem. Earth, 2014, 67-69, 140-144.

52 P. K. Westerhoff, M. A. Kiser and K. Hristovski, Environ. Eng. Sci., 2013, 30, 109-117.

53 L. K. Limbach, R. Bereiter, E. Müller, R. Krebs, R. Gälli and W. J. Stark, Environ. Sci. Technol., 2008, 42, 5828-5833.

54 R. Ganesh, J. Smeraldi, T. Hosseini, L. Khatib, B. H. Olson and D. Rosso, Environ. Sci. Technol., 2010, 44, 7808-7813.

55 E. F. C. Chaúque, J. N. Zvimba, J. C. Ngila and N. Musee, Water SA, 2016, 42(1), 72-80.

56 C. Levard, E. M. Hotze, G. V. Lowry and G. E. Brown, Environ. Sci. Technol., 2012, 46, 6900-6914.

57 R. Kaegi, A. Voegelin, B. Sinnet, S. Zuleeg, H. Hagendorfer, M. Burkhardt and H. Siegrist, Environ. Sci. Technol., 2011, 45, 3902-3908.

58 L. Hou, K. Li, Y. Ding, Y. Li, J. Chen, X. Wu and X. Li, Chemosphere, 2012, 87, 248-252.

59 R. Kaegi, A. Voegelin, C. Ort, B. Sinnet, B. Thalmann, J. Krismer, H. Hagendorfer, M. Elumelu and E. Mueller, Water Res., 2013, 47, 3866-3877.

60 P. Westerhoff, G. X. Song, K. Hristovski and M. A. Kiser, J. Environ. Monit., 2011, 13(5), 1195-1203.

61 H. P. Jarvie, H. Al-Obaidi, S. M. King, M. J. Bowes, M. J. Lawrence, A. F. Drake, M. A. Green and P. J. Dobson, Environ. Sci. Technol., 2009, 43, 8622-8628.

62 L. Otero-González, J. A. Field, I. A. C. Calderon, C. A. Aspinwall, F. Shadman, C. Zeng and R. SierraAlvarez, Water Res., 2015, 77, 170-178.

63 H. He, Y. Cheng, C. Yang, et al., J. Environ. Sci., 2017, 54, 135-141.

64 H. He, Y. Chen, X. Li, et al., Int. Biodeterior. Biodegrad., 2017, 119, 520-527.

65 S. K. Misra, A. Dybowska, D. Berhanu, S. N. Luoma and E. Valsami-Jones, Sci. Total Environ., 2012, 438, 225-232.

66 L. Otero-González, I. Barbero, J. A. Field, F. H. Shadman and R. Sierra-Alvarez, Water Sci. Technol., 2014, 70(9), 15331539.

67 N. M. Franklin, N. J. Rogers, S. C. Apte, G. E. Batley, G. E. Gadd and P. S. Casey, Environ. Sci. Technol., 2007, 41(24), 8484-8490.

68 E. Lombi, E. Donner, E. Tavakkoli, T. W. Turney, R. Naidu, B. W. Miller and K. G. Scheckel, Environ. Sci. Technol., 2012, 46, 9089-9096.

69 N. Musee, J. N. Zvimba, L. M. Schaefer, N. Nota, L. M. Sikhwivhilu and M. Thwala, J. Environ. Sci. Health, Part A: Toxic/Hazard. Subst. Environ. Eng., 2014, 49, 59-66.

70 Y. Liu, J. Baas, W. J. G. M. Peijnenburg and M. G. Vijver, Environ. Sci. Technol., 2016, 50, 5328-5337.

71 S. Yu, Y. Yin, J. Chao, M. Shen and J. Liu, Environ. Sci. Technol., 2014, 48, 403-411. 
72 R. Ma, C. Levard, F. M. Michel, G. E. Brown and G. V. Lowry, Environ. Sci. Technol., 2013, 47, 2527-2534.

73 B. Wu, Y. Wang, Y. Lee, A. Horst, Z. Wang, D. Chen, R. Sureshkumar and Y. J. Tang, Environ. Sci. Technol., 2010, 44, 1484-1489.

74 N. M. Franklin, N. J. Rogers, S. C. Apte, G. E. Batley, G. E. Gadd and P. S. Casey, Environ. Sci. Technol., 2007, 41, 8484-8490.

75 Y. Yang, J. Wang, Z. Xiu and P. J. J. Alvarez, Environ. Toxicol. Chem., 2013, 32(7), 1488-1494.

76 Z. Yuan, J. Li, L. Cui, B. Xu, H. Zhang and C. Yu, Chemosphere, 2013, 90, 1404-1411.

77 T. S. Radniecki, D. P. Stankus, A. Neigh, J. A. Nason and L. Semprini, Chemosphere, 2011, 85, 43-49.

78 Z. Sheng and Y. Liu, Water Res., 2011, 45, 6039-6050.

79 J. Chen, Y. Tang, Y. Li, Y. Nie, L. Hou, X. Li and X. Wu, Chemosphere, 2014, 104, 141-148.

80 C. L. Alito and C. K. Gunsch, Environ. Sci. Technol., 2014, 48, 970-976.

81 C. L. Doolette, M. J. McLaughlin, J. K. Kirby, D. J. Batstone, H. H. Harris, H. Q. Ge and G. Comelis, Chem. Cent. J., 2013, 7, 1-18.

82 C. Zhang, Z. Liang and Z. Hu, Water Res., 2014, 50, 350-358.

83 Y. Chen, D. Wang, X. Zhu, X. Zheng and L. Feng, Environ. Sci. Technol., 2012, 46, 12452-12458.

84 X. Zheng, R. Wu and Y. Chen, Environ. Sci. Technol., 2011, 45, 2826-2832.

85 L. Hou, J. Xia, K. Li, J. Chen, X. Wu and X. Li, Water Sci. Technol., 2013, 67(2), 254-260.

86 S. T. Wang, S. P. Li, W. Q. Wang and H. You, RSC Adv., 2015, 5, 67335-67342.

87 D. Li, F. Cui, Z. Zhao, D. Liu, Y. Xu, H. Li and X. Yang, Biodegradation, 2014, 25, 167-177.
88 Y. Chen, Y. Su, X. Zheng, H. Chen and H. Yang, Water Res., 2012, 46, 4379-4386.

89 X. Zheng, Y. Su and Y. Chen, Environ. Sci. Technol., 2012, 46, 7182-7188.

90 D. Wu, Y. Shen, A. Ding, Q. Mahmood, S. Liu and Q. Tu, J. Hazard. Mater., 2013, 262, 649-655.

91 S. Ni, J. Ni, N. Yang and J. Wang, Bioresour. Technol., 2013, 143, 555-561.

92 H. Chen, X. Zheng, Y. Chen and H. Mu, RSC Adv., 2013, 3, 9835-9842.

93 Y. Chen, H. Chen, X. Zheng and H. Mu, J. Hazard. Mater., 2012, 239-240, 88-94.

94 X. Sun, Z. Sheng and Y. Liu, Sci. Total Environ., 2013, 443, 828-835.

95 E. Jeong, W. Im, D. Kim, M. Kim, S. Kang, H. Shin and S. Chae, J. Environ. Sci. Health, Part A: Toxic/Hazard. Subst. Environ. Eng., 2014, 49, 685-693.

96 L. Otero-González, J. A. Field and R. Sierra-Alvarez, J. Environ. Manage., 2014, 135, 110-117.

97 J. Hou, L. Z. Miao, C. Wang and P. F. Wang, J. Hazard. Mater., 2014, 276, 164-170.

98 H. Mu, X. Zheng, Y. Chen, H. Chen and K. Liu, Environ. Sci. Technol., 2012, 46, 5997-6003.

99 J. Gonzalez-Estrella, R. Sierra-Alvarez and J. A. Field, J. Hazard. Mater., 2013, 260, 278-285.

100 J. Hou, L. Z. Miao, C. Wang, P. F. Wang, Y. H. Ao and B. W. Lv, Bioresour. Technol., 2015, 176, 65-70.

101 L. Otero-González, J. A. Field and R. Sierra-Alvarez, Water Res., 2014, 58, 160-168.

102 H. Chen, Y. Chen, X. Zheng, X. Li and J. Y. Luo, Water Res., 2014, 63, 125-134.

103 M. Sibag, B.-G. Choi, C. Suh, K. H. Lee, J. W. Lee, S. K. Maeng and J. Cho, J. Hazard. Mater., 2015, 283, 841846. 